\title{
Use of Thistle meal (Silybum marinum) as additive to improve nutritional and protective qualities of sausages
}

\author{
A.S. Dzhaboeva ${ }^{1}$, D.V. Osepchuk ${ }^{2}$, Y.N. Ashinov ${ }^{3}$, A.A. Stolbovskaya ${ }^{4}$, \\ I.V. Kochieva ${ }^{4}$, A.V. Khmelevskaya ${ }^{5}$, L.A. Bobyleva ${ }^{5}$, R.B. Temiraev ${ }^{4}$, \\ M.G. Kokaeva ${ }^{4}$
}

${ }^{1}$ Chair of Food Technology Products, Kabardino-Balkarian State Agrarian University named after Kokov, Nalchik 360030, ${ }^{2}$ Department of Animal Feeding and Physiology. Krasnodar Research Centre for Animal Husbandry and Veterinary Medicine, Krasnodar 350055, ${ }^{3}$ Chairs of Technology of Production of Agricultural Products, Maykop State Technological University, Maykop 385000, ${ }^{4}$ Chair of Technology of Food Products, North-Caucasian Mining and Metallurgical Institute (State Technological University), Vladikavkaz 362021, ${ }^{5}$ Chairs of Anatomy, Physiology and Botany, North-Ossetian State University named after K.L. Khetagurov, Vladikavkaz, 362025, Russian Federation.

Journal of Livestock Science (ISSN online 2277-6214) 10:114-117

Received on 06/09/2019; Accepted on 2/11/2019

doi. 10.33259/JLivestSci.2019.114-117

\begin{abstract}
Thistle meal is characterized by a high content of dry matter and protein, which causes its use as a protein food additive. In addition, thistle meal is characterized by a high content of structural fibrous carbohydrates of fiber, hemicellulose and pectin substances that allows to adsorb heavy metals and remove them from the gastrointestinal tract. The research aims to study the possibility of thistle meal introduction into the formulation of Bavarian sausages to increase their consumer and protective properties. Soybean protein isolate at the rate of $2 \%$ by weight was introduced into the mince of Bavarian sausages control sample. Thistle meal at the rate of $2 \%$ was added instead of soybean protein isolate to the test sample. The introduction of thistle meal at the rate of $2 \%$ into the mince is accompanied by some increase of moisture in the product with a slight increase in the level of protein substances. The ratio of protein:fat in the test sample is higher than that of the control by $12.9 \%$. The analysis of the structural and mechanical properties of the test sample shows that the sausages cut stress containing thistle meal is higher than that of the control sample. When introducing thistle meal into the product instead of soybean protein isolate, the moisture-retaining power of the test sample increased by 2.1 and $1.8 \%$, respectively. The moisture-retaining power of the test sample decreased by $1.7 \%$ relative to the control. The test sample of finished products contained more than $0.8 \%$ of protein and less than $1.1 \%$ of fat and calories. By the point total, the control sample of Bavarian sausages was significantly $(\mathrm{P}>0.95)$ inferior to the test sample of a meat product, in the formulation of which the thistle meal was used. By the end of the laboratory experiment the lead content in the rats blood of the test group relative to the control group of animals was significantly $(\mathrm{P}>0.95) 2$ times lower. Moreover, its level in the blood did not exceed the maximum permissible concentration (MPC).
\end{abstract}

Keywords: Bavarian sausages, Silybum marinum; thistle meal; properties of meat products 


\section{Introduction}

Among many pollutants of chemical nature, a special place is occupied by heavy metals, the biological significance of which is determined by high toxicity (accumulation in the body has a negative polytropic effect). The Republic of North Ossetia-Alania belongs to the most contaminated with heavy metals areas in Russia due to the high concentration of non-ferrous metallurgy enterprises in the city of Vladikavkaz. Studies of some authors have also shown that the main soil pollutants in the republic are acid-soluble metals: lead, zinc, cadmium and copper (Baeva et al., 2014; Tsalieva et al., 2017).

Thistle meal (Silybum marinum) is characterized by a high content of dry matter $-95.40 \%$, protein $-34.20 \%$, which causes its use as a protein food additive. In addition, thistle meal is characterized by a high content of structural fibrous carbohydrates of fiber $-22.5 \%$, hemicellulose -10.905 and pectin $-5.96 \%$, which allows to activate intestinal peristalsis, adsorb heavy metals and remove them from the gastrointestinal tract (Zolotareva et al., 1998; Temiraev et al., 2017). High protective properties of thistle meal are determined both by the high content of cellulose, hemicellulose and the presence of flavolignans. At the same time, the adsorption properties of flavonoid meal components are estimated by the content of silibinin, represented in the thistle with silibinin A and silibinin B. In particular, their content $0.188 \mathrm{mg} / \mathrm{kg}$ in the thistle is very high (Tedtova et al., 2017; Yarmots et al., 2013). Taking into account the listed thistle qualities, its processing by-product thistle meal is a promising food additive in the organization of therapeutic and preventive nutrition in regions with a high level of environmental pollution by chemical toxicants.

The present work aims to study the possibility of thistle meal introduction into the formulation of Bavarian sausages to increase their consumer and protective properties.

\section{Material and methods}

Bavarian sausages used in the present study were produced from defrosted meat after preliminary salting and raw materials ageing within 24 hours. The formulation traditionally applicable at the enterprise LLC "Myasoproduct" (Vladikavkaz) was used to produce the control sample of Bavarian sausages.

In the course of the research, two samples of Bavarian sausages were made using in the formulation (table 1) samples of minced sausage with soybean protein isolate (control sample) and thistle meal (test sample). Soybean protein isolate at the rate of $2 \%$ by weight was introduced into the control minced Bavarian sausages sample. Instead of soybean protein isolate, thistle meal at the rate of $2 \%$ was added to the test sample. In the formulation of Bavarian sausages test sample the thistle meal (producer company "Ivan da Marya" Penza region, Russia) was used. All the used ingredients including soybean protein isolate (included in the formulation of the control sample) and thistle meal met the requirements.

Table 1 - Composition and formulation of Bavarian sausages

\begin{tabular}{|l|c|c|}
\hline \multirow{2}{*}{ Indicators } & \multicolumn{2}{|c|}{$100 \mathrm{~kg}$ sample contains } \\
\cline { 2 - 3 } & control & test \\
\hline Finished product defect & 4 & 4 \\
\hline Animals rimming. Minced beef & 10 & 10 \\
\hline Chicken leg-breast & 15.5 & 15,5 \\
\hline Vein emulsion & 10 & 10 \\
\hline Water/ice & 12.5 & 12,5 \\
\hline Semifat pork & 22.5 & 22,5 \\
\hline Mid-back fat & 7.8 & 7,8 \\
\hline Water/ice & 10 & 10 \\
\hline Cheese & 6 & 6 \\
\hline Soybeanprotein isolate & 2.0 & - \\
\hline Thistle meal & - & 2,0 \\
\hline Starch & 1.7 & 1,7 \\
\hline Emulsifiers & 0.5 & 0,5 \\
\hline Garlic & 0.1 & 0,1 \\
\hline Salt & 05 & 0,5 \\
\hline Frankfurter Kombi 5213 & 0.67 & 0,67 \\
\hline Baksolan-4 & 0.15 & 0,15 \\
\hline
\end{tabular}

All studies of the physical and chemical properties in the compared samples of Bavarian sausages were carried out using conventional methods. The results obtained in the course of research were processed by mathematical analysis software "Microsoft Excel". 


\section{Results and Discussion}

When preparing minced meat for the compared samples of Bavarian sausages, a number of physical and chemical properties were studied (table 2). Comparison of quality indicators in control and test minced Bavarian sausages samples shows that the introduction of thistle meal at the rate of $2 \%$ into the minced meat is accompanied by some increase of moisture in the product with a slight increase in the level of protein substances. The ratio of protein:fat in the test sample is higher than the control by $12.9 \%$. Analysis of the structural and mechanical properties of the test sample shows that the cut stress of sausages containing thistle meal is higher than that of the control sample. This may indicate that the test sample of Bavarian sausages has more elastic consistency.

During the experiment, the $\mathrm{pH}$, moisture and moisture-retaining power of minced sausage and finished products were studied (table 3). It was found that the acidity of the test sample is close to the $\mathrm{pH}$ value of the control sample. This is due to the fact that thistle meal and soybean protein isolate have almost neutral medium reaction. When introducing thistle meal instead of soybean protein isolate into the product, the moisture-retaining power of the test sample increased by 2.1 and $1.8 \%$, respectively. Relative to the control there has been the decrease of moisture-retaining power in the test sample by $1.7 \%$, which can be explained by some change in the moisture content of this sample due to the introduction of thistle meal that contains more moisture content than meat raw materials.

During the research, the chemical composition and energy value of the compared samples of Bavarian sausages were studied (table 4). It was found that the test sample of finished products contained more that $0,8 \%$ of protein and less than $1.1 \%$ of fat and calories.

To assess the effect of thistle meal in the Bavarian sausages composition on the quality of meat products, a seven-member taste panel conducted an organoleptic assessment of the stated dish samples. Statistical processing of the organoleptic assessment results of the compared samples showed that by the point total the control Bavarian sausages sample was significantly $(\mathrm{p}>0.95) 1.5$ points inferior to the test sample of the meat product, in the formulation of which the thistle meal was used. It is believed that as regard to the control sample the increase in consumer properties of the test Bavarian sausages sample was provided by the increase of protein and glutamic acid in the finished product.

To assess the detoxification properties of food products, in vivarium of the Department of anatomy, physiology and human and animal hygiene in the North Ossetian state university named after K.L. Khetagurov 10-day experiment using laboratory Wistar rats divided by analogue scale into control and test groups of 3 animals each was conducted. Animals of the compared groups got lead sulfate $\left(\mathrm{PbSO}_{4}\right)$ as part of their diet. Rats of the control group were fed Bavarian sausages with soybean protein isolate, and animals of the test group were fed sausages supplemented with thistle meal at the rate of $2 \%$. The results of the analysis of blood samples from animals in the compared groups for the lead presence are given in table 5.

It was found that by the end of the experiment the lead content in rats blood of the control group increased more than 2 times and exceeded the maximum permissible concentration (MPC). As for the control, by the end of the experiment the lead content in rats blood of the test group was significantly ( $\mathrm{P}>0.95) 2$ times lower. And its level in blood did not exceed the MPC.

Table 2 - Quality indicators of Bavarian sausages

\begin{tabular}{|l|c|c|c|c|}
\hline \multirow{2}{*}{ Indicators } & \multicolumn{2}{|c|}{ Control sample } & \multicolumn{2}{c|}{ Test sample } \\
\cline { 2 - 5 } & Mean & SE & Mean & SE \\
\hline Moisture, \% & 65.87 & 0.181 & 67.57 & 0.111 \\
\hline Protein, \% & 12.99 & 0.101 & 13.30 & 0.120 \\
\hline Fat, \% & 18.46 & 0.130 & 16.81 & 0.101 \\
\hline Ash, \% & 2.34 & 0.050 & 1.96 & 0.030 \\
\hline Cut stress, $\mathrm{kPa}$ & 19.78 & 0.21 & 21.31 & 0.19 \\
\hline Protein,fat & \multicolumn{3}{|c|}{0.70} & \multicolumn{2}{c|}{0.79} \\
\hline
\end{tabular}

Table 3 - pH value, moisture and moisture-retaining power of minced meat and finished sausages

\begin{tabular}{|c|c|c|c|c|}
\hline \multicolumn{2}{|c|}{ Samples } & $\mathrm{pH}$ & Moisture, $\%$ & Moisture-retaining power, \% \\
\hline \multirow{2}{*}{$\begin{array}{c}\text { Minced } \\
\text { sausage }\end{array}$} & Control & 5.85 & 64.80 & 60.15 \\
\cline { 2 - 5 } Finished & Test & 5.86 & 67.60 & 58.80 \\
\cline { 2 - 5 } product & Control & 6.00 & 64.50 & 51.48 \\
\cline { 2 - 5 } & Test & 6.00 & 67.10 & 49.74 \\
\hline
\end{tabular}


Table 4 - Nutritional value of Bavarian sausage samples, per $100 \mathrm{~g}$ of product

\begin{tabular}{|l|c|c|c|c|c|}
\hline \multicolumn{1}{|c|}{ Samples } & Water, g & Protein, g & \multirow{2}{*}{ Fat, g } & \multicolumn{2}{|c|}{ Energy value } \\
\cline { 4 - 6 } & & & & Kcal & $\mathrm{Kj}$ \\
\hline Control & 39.0 & 16.1 & 40.1 & 425 & 1778 \\
\hline Test & 39.1 & 17.3 & 39.0 & 420 & 1757 \\
\hline
\end{tabular}

Table 5 - Lead content in the blood of experimental animals

\begin{tabular}{|l|c|c|c|}
\hline \multirow{2}{*}{$\begin{array}{c}\text { Group of } \\
\text { animals }\end{array}$} & \multirow{2}{*}{$\begin{array}{c}\text { MPC, } \\
\mathrm{mg} / \mathrm{kg}\end{array}$} & \multicolumn{2}{c|}{ Lead content in blood, $\mathrm{mg} / \mathrm{kg}$} \\
\cline { 3 - 4 } & 0.12 & at the start of the experiment & at the end of the experiment \\
\hline Control & 0.12 & $0.070 \pm 0.003$ & $0.150 \pm 0.002$ \\
\hline Test & $0.070 \pm 0.003$ & $0.075 \pm 0.003$ \\
\hline
\end{tabular}

Conclusion The formulation of Bavarian sausages supplemented with thistle meal at the rate of $2 \%$ by raw materials weight instead of soybean protein isolate significantly increase their consumer and detoxification qualities. This makes it possible to recommend using the thistle meal at the given rate in the Bavarian sausages formulation during organization of therapeutic and preventive nutrition of consumers living in regions with high levels of heavy metal pollution.

\section{References}

1). Baeva, A.A., Ktsoeva I.I, Abaev A.V., Vityuk L.A., Kovaleva Yu.I., Payuchek V.G. 2014. Use of sorbents in the diet to enhance the ecological and nutritional value of broilers meat. Polythematic online scientific journal of Kuban State Agrarian University (Scientific journal of KubSAU) [Electronic resource]. - Krasnodar: KubSAU,. 7(101): 2510-2520 IDA [article ID]: 1011407167. Access mode: http://ej.kubagro.ru/2014/07/pdf/167.pdf.

2). Tsalieva, L.V., Temiraev R.B., Kononenko S.I., Dzagurov B.A., Gazzaeva M.S., Grevtsova S.A 2017. Ecological and consumer properties of pig meat from different breeds produced in technogenic zone. Journal of Pharmaceutical Sciences and Research 9(12): 2397-2400.

3). Zolotareva, A.N., Chirkina T.F., Tsybikova D.Ts., Babueva Ts.M. 1998 Study of functional properties of thistle meal. Chemistry of plant raw materials 1:29-32.

4). Temiraev, R.B., Kozhokov M.K., Cherchesova S.K., Kokaeva F.F., Tletseruk I.R. 2017 Method for diminishing the adverse effect of anthropogenic heavy metal pollution on poultry meat products. Journal of Environmental Management and Tourism. Vol 8 №3(19): 567-573.

5). Tedtova, V.V., Kozkhokov M.K., Shugusheva L.H., Kanukova V.N., Baeva A.A., Vityuk L.A. 2017. Preventive and detoxicative action of probiotics on metabolism and consumer quality of broilers meat. Journal of Pharmaceutical Sciences and Research. 9(6): 997-1001.

6). Yarmots, A.V., Temiraev R.B., Vityuk L.A., Kokaeva M.G., Plieva Z.K. 2013. Way to improve the ecological and nutritional qualities of milk and dairy products. New technologies - Maykop 3: 128-134. 